EXTENDED REPORT

\title{
Diffuse diabetic macular oedema treated by intravitreal triamcinolone acetonide: a comparative, non-randomised study
}

\author{
J B Jonas, I Akkoyun, I Kreissig, R F Degenring
}

Br J Ophthalmol 2005;89:321-326. doi: 10.1136/bjo.2004.046391

\begin{abstract}
See end of article for authors' affiliations

.....................

Correspondence to: Dr J Jonas, UniversitätsAugenklinik, TheodorKutzer-Ufer 1-3, 68167 Mannheim, Germany; Jost.Jonas@ma.augen. uni-heidelberg.de

Accepted for publication 7 July 2004
\end{abstract}

\begin{abstract}
Aim: To report on visual outcome of patients receiving an intravitreal injection of triamcinolone acetonide for treatment of diffuse diabetic macular oedema.

Methods: Prospective, comparative, non-randomised clinical interventional study included 136 patients with diffuse diabetic macular oedema. Patients of the study group (97 eyes) received an intravitreal injection of 20-25 mg of triamcinolone acetonide and no other retinal treatment. Patients of the control group (69 eyes) received focal or panretinal laser treatment if indicated. Mean (standard deviation) follow up was 8.4 (SD 6.0) months (range 1.03-25.2 months).

Results: Visual acuity (VA) increased significantly $(p<0.001)$ in the study group with $66(68 \%)$ eyes gaining in VA by at least two Snellen lines. In the control group, VA did not change significantly during the first 4 months of follow up, and decreased significantly $(p<0.001)$ towards the end of the follow up. Difference in change of best VA was significant $(p<0.001)$ between both groups. Correspondingly, the number of patients with VA improvement of two or more Snellen lines and visual loss of two or more Snellen lines, respectively, was significantly $(p<0.001)$ higher and lower, respectively, in the study group. Conclusions: Intravitreal triamcinolone acetonide can temporarily increase VA in some patients with diffuse diabetic macular oedema.
\end{abstract}

$\mathrm{R}$ ecent investigations have reported on the use of intravitreal triamcinolone acetonide for treatment of diabetic macular oedema. ${ }^{1-4}$ These studies were either single patient reports or non-comparative case series studies without a control group. As the course of diabetic macular oedema varies from person to person, and includes the possibility of spontaneous improvement, the purpose of the present study was to investigate in a comparative study design whether the anti-angiogenic, anti-proliferate, and anti-oedematous effect of intravitreal triamcinolone acetonide can be used to treat patients with diffuse diabetic macular oedema.

\section{PATIENTS AND METHODS}

This clinical, interventional, prospective, comparative nonrandomised study included 166 eyes (136 patients) with diffuse diabetic macular oedema according to the Early Treatment Diabetic Retinopathy Study (ETDRS) definition. ${ }^{56}$ The study group, consisting of 97 eyes of 81 consecutive patients (46 women; 43 right eyes), received an intravitreal injection of about $20-25 \mathrm{mg}$ triamcinolone acetonide as the only retinal treatment. The control group (69 eyes-55 patients; 30 women; 32 right eyes) did not receive an intravitreal injection of triamcinolone nor a macular grid laser treatment during the follow up. Most of the patients in the control group had already been lasered before inclusion into the study. They had received scatter panretinal laser coagulation, and/or a focal laser coagulation according to ETDRS guidelines. During follow up, they underwent focal laser treatment if indicated by fluorescein angiography, according to the guidelines. The main reason for assigning the patients to the study group or the control group was based on their preference: control group patients did not want an intravitreal injection of triamcinolone acetonide.

For all patients, VA at baseline of the study ranged between finger counting and 0.60 . During the follow up, no additional ocular surgery (including cataract operation) was carried out. Because of the distribution of patients in the study group and control group, both groups did not vary significantly in preoperative intraocular pressure (IOP) $(p=0.88)$, age $(p=0.56)$, refractive error $(p=0.60)$, sex $(p=0.44)$, right or left eye $(p=0.46)$, or follow up $(p=0.30)$ (table 1$)$. Preoperative VA was significantly higher in the control group than in the study group (table 1).

For that reason, an additional control group was formed adjusted for preoperative visual acuity (VA) with the study group. The study group and the adjusted control group did not vary significantly in preoperative IOP $(p=0.92)$, age $(p=0.05)$, refractive error $(p=0.25)$, follow up $(p=0.53)$, sex $(p=0.07)$, or right or left eye $(p=0.51)$ (table 2$)$. The patients in the study group and those in the control group adjusted for preoperative VA with the study group were observed in the same way, their VA was tested with the same technique, and the degree of macular oedema was similar.

All patients receiving the intravitreal injection were fully informed about the experimental character of the treatment and signed an informed consent. The ethics committee of the university had approved the study which followed the tenets of the Declaration of Helsinki.

All patients received an intravitreal injection of about 20-25 mg triamcinolone acetonide in $0.2 \mathrm{ml}$ Ringer's solution as previously described in detail. ${ }^{4}$ At baseline of the study, VA and IOP were determined and fluorescein angiography was performed. After inclusion into the study, the patients in the study group and those in the control group were re-examined. The study group patients were reexamined the first day after injection, followed by reexaminations at about 1 month intervals. The control group patients were re-examined at roughly 2 month intervals.

Abbreviations: ETDRS, Early Treatment Diabetic Retinopathy Study; $I O P$, intraocular pressure; $V A$, visual acuity. 
Table 1 Baseline data of the patients of the study group and the control group

\begin{tabular}{|c|c|c|c|}
\hline & $\begin{array}{l}\text { Study group } \\
(\mathrm{n}=97)\end{array}$ & $\begin{array}{l}\text { Control group } \\
(n=69)\end{array}$ & p Value* \\
\hline Age (years) & $67.2(9.9)$ & $66.7(8.6)$ & 0.56 (NS) \\
\hline Median & 67.5 & 67.8 & \\
\hline Range & $28.2-86.7$ & $49.1-87.5$ & \\
\hline Refractive error (D) & $0.61(1.55)$ & $0.69(1.43)$ & 0.60 (NS) \\
\hline Median & +0.50 & +0.63 & \\
\hline $\begin{array}{l}\text { Range } \\
\text { Visual acuity }\end{array}$ & -2.5 to +5.25 & -3.75 to +5.75 & \\
\hline Snellen acuity & $0.14(0.09)$ & $0.31(0.16)$ & $<0.001$ \\
\hline Median & 0.10 & 0.30 & \\
\hline Range & FC- 0.50 & $0.03-0.60$ & \\
\hline Snellen lines & $13.3(3.2)$ & $17.1(2.9)$ & $<0.001$ \\
\hline Median & 13 & 18 & \\
\hline Range & $4-20$ & $8-21$ & \\
\hline LogMar & $0.98(0.36)$ & $0.59(0.52)$ & $<0.001$ \\
\hline Median & 1.00 & 0.53 & \\
\hline Range & $0.30-2.40$ & $0.22-1.52$ & \\
\hline Follow up & $9.2(6.8)$ & $7.4(4.5)$ & 0.30 (NS) \\
\hline Median & 7.0 & 6.9 & \\
\hline Range & $1.0-25.2$ & $1.2-23.1$ & \\
\hline Intraocular pressure & $15.2(3.6)$ & $15.5(3.6)$ & 0.85 (NS) \\
\hline Median & 16 & 16 & \\
\hline Range & $10-24$ & $9-24$ & \\
\hline \multicolumn{4}{|l|}{ Change in best VA } \\
\hline LogMar units & $-0.27(0.24)$ & $0.03(0.21)$ & $<0.001$ \\
\hline Snellen lines & $2.6(2.2)$ & $-0.3(1.9)$ & $<0.001$ \\
\hline Snellen acuity & $0.12(0.13)$ & -0.0210 .120 & $<0.001$ \\
\hline \multicolumn{4}{|c|}{$\begin{array}{l}\text { Change in VA between } \\
\text { baseline and end of } \\
\text { follow up }\end{array}$} \\
\hline LogMar units & $-0.03(0.33)$ & $0.13(0.23)$ & $<0.001$ \\
\hline Snellen lines & $0.4(3.3)$ & $-1.3(2.3)$ & $<0.001$ \\
\hline Snellen acuity & $0.03(0.13)$ & $-0.07(0.12)$ & $<0.001$ \\
\hline \multicolumn{4}{|c|}{$\begin{array}{l}\text { *Statistical significance of difference between the two groups. } \\
\text { NS, statistically not significant; VA, visual acuity. Results shown as mean } \\
\text { (standard deviation). }\end{array}$} \\
\hline
\end{tabular}

Mean (standard deviation) follow up was 8.4 (SD 6.0) months (range 1.03-25.2 months) (tables 1 and 2). Visual acuity was determined in a standardised fashion by an observer performing best corrected refractometry and using Snellen charts. The VA measurements were given as Snellen lines and in metric units. Additionally, they were converted to the logarithm of the minimum angle of resolution ( $\log M A R)$

Statistical analyses were performed by using a commercially available statistical software package (SPSS for Windows, version 11.5, SPSS, Chicago, IL, USA). To test the statistical significance of differences between the study group and the control group, the Mann-Whitney test, Wilcoxon test, or Student's $t$ test for parameters such as IOP and VA were used. For parameters such as sex and right or left eye, the $\chi^{2}$ test was applied. The level of significance was 0.05 (two sided) in all statistical testing.

\section{RESULTS}

In the study group, an increase in best VA during the follow up was found in $82(84.5 \%)$ eyes. In $12(12.3 \%)$ eyes, preoperative VA and best postoperative VA did not vary (fig 1). The change in best VA was on the average 0.12 (SD 0.13 ) (logMar units: -0.27 (SD 0.24)) (table 1) indicating a significant $(p<0.001)$ increase in VA compared with the baseline value. Expressing VA in Snellen units showed a similar result with a mean increase in VA by 2.6 (SD 2.2) Snellen lines (table 1) (fig 1). In 66 (68\%) eyes, best VA increased by at least two Snellen lines (fig 1). Comparing preoperative VA measurements with the measurements obtained at each of the follow up visits, the differences were statistically significant for the measurements performed 1 to 5 months and 7 months after the injection (table 3). For
Table 2 Baseline data of the study group patients and a control group matched for preoperative visual acuity with the study group

\begin{tabular}{|c|c|c|c|}
\hline & $\begin{array}{l}\text { Study group } \\
(\mathrm{n}=77)\end{array}$ & $\begin{array}{l}\text { Control group } \\
(n=39)\end{array}$ & p Value* \\
\hline Age (years) & $66.5(10.1)$ & $70.5(7.4)$ & 0.05 (NS) \\
\hline Median & 66.1 & 71.1 & \\
\hline Range & $28.2-86.7$ & $51.2-87.5$ & \\
\hline Refractive error (D) & 0.73 (1.59) & $0.96(1.09)$ & 0.25 (NS) \\
\hline Median & +0.50 & +0.88 & \\
\hline Range & -2.5 to +5.25 & -0.75 to +4.00 & \\
\hline \multicolumn{4}{|l|}{ Visual acuity } \\
\hline Snellen acuity & $0.16(0.09)$ & $0.19(0.08)$ & 0.08 (NS) \\
\hline Median & 0.13 & 0.20 & \\
\hline Range & $0.06-0.50$ & $0.03-0.30$ & \\
\hline Snellen lines & $14.5(2.3)$ & $15.2(2.5)$ & 0.07 (NS) \\
\hline Median & 14 & 16 & \\
\hline Range & $11-20$ & $8-18$ & \\
\hline LogMar & $0.85(0.23)$ & $0.79(0.25)$ & 0.08 (NS) \\
\hline Median & 0.90 & 0.70 & \\
\hline Range & $0.30-1.22$ & $0.52-1.52$ & \\
\hline Follow up & $8.9(6.3)$ & $7.7(4.7)$ & 0.53 (NS) \\
\hline Median & 6.8 & 7.5 & \\
\hline Range & $1.33-24.1$ & $1.2-17.7$ & \\
\hline Intraocular pressure & $15.3(3.6)$ & $15.4(3.0)$ & 0.92 (NS) \\
\hline Median & 16 & 16 & \\
\hline Range & $10-24$ & $9-24$ & \\
\hline \multicolumn{4}{|l|}{ Change in best VA } \\
\hline LogMar units & $-0.24(0.21)$ & $-0.01(0.23)$ & $<0.001$ \\
\hline Snellen lines & $2.4(2.1)$ & $0.1(2.0)$ & $<0.001$ \\
\hline Snellen acuity & $0.13(0.13)$ & $0.02(0.08)$ & $<0.001$ \\
\hline \multicolumn{4}{|c|}{$\begin{array}{l}\text { Change in VA between } \\
\text { baseline and end of } \\
\text { follow up }\end{array}$} \\
\hline LogMar units & $0.00(0.33)$ & $0.09(0.21)$ & 0.04 \\
\hline Snellen lines & $0.1(3.2)$ & $-1.0(2.1)$ & 0.03 \\
\hline Snellen acuity & $0.03(0.14)$ & $-0.03(0.08)$ & 0.02 \\
\hline \multicolumn{4}{|c|}{$\begin{array}{l}\text { *Statistical significance of difference between study group and control } \\
\text { group. } \\
\text { NS, statistically not significant; VA, visual acuity. Results are shown as } \\
\text { mean (standard deviation). }\end{array}$} \\
\hline
\end{tabular}

measurements obtained at 6 months or 8 months or later after the injection, the differences between the baseline examinations and the examinations performed during the follow up were statistically not significant (table 3 ). The lack of a statistical significance might have been due to a lower number of patients at the follow up visits. There was a tendency of a reduction of VA towards the end of the follow up (table 3). Visual acuity measurements obtained at the end of the follow up, however, were still significantly higher $(p=0.02)$ than those obtained at baseline of the study.

In the control group, an increase in best VA during follow up was found in 23 (33\%) eyes, and a decrease in 27 (39\%) eyes when compared with the baseline VA (fig 1). In 19 $(28 \%)$ eyes, baseline VA and best VA during follow up did not vary. In 10 (14\%) eyes, best VA increased by at least two Snellen lines. Best VA changed by -0.02 (SD 0.12) (logMar units: 0.03 (SD 0.21)) or -0.30 (SD 1.9) Snellen lines (table 2). Comparing baseline VA measurement with the measurements obtained at each of the follow up visits, the differences were statistically not significant for the measurements for the first 4 months after baseline. For the measurements performed 5 months and 6 months, respectively, after the injection, VA was significantly lower compared with the baseline value $(\mathrm{p}=0.01$, and $\mathrm{p}=0.02$, respectively). Comparing VA measurements obtained at the end of follow up with the VA measurements obtained at baseline, the control group showed a significant $(p<0.001)$ loss in VA.

Comparing the study group and control group with each other, the differences in change in best VA between the groups-measured in logMar units, Snellen acuity, or Snellen 


\begin{tabular}{|c|c|c|}
\hline & Study group & p Value* \\
\hline \multicolumn{3}{|c|}{ VA at baseline $(n=97)$} \\
\hline LogMar & $0.98(0.36)$ & \\
\hline Snellen lines & $13.3(3.2)$ & \\
\hline Snellen acuity & $0.14(0.10)$ & \\
\hline \multicolumn{3}{|c|}{ VA affer 1 week $(n=57)$} \\
\hline LogMar units & $0.86(0.32)$ & 0.001 \\
\hline Snellen lines & $14.4(3.2)$ & 0.001 \\
\hline Snellen acuity & $0.18(0.15)$ & 0.002 \\
\hline \multicolumn{3}{|c|}{ VA after 1 month $(n=64)$} \\
\hline LogMar units & $0.83(0.37)$ & $<0.001$ \\
\hline Snellen lines & $14.7(3.7)$ & $<0.001$ \\
\hline Snellen acuity & $0.20(0.14)$ & $<0.001$ \\
\hline \multicolumn{3}{|c|}{ VA after 2 months $(n=52)$} \\
\hline LogMar units & $0.81(0.33)$ & $<0.001$ \\
\hline Snellen lines & $14.8(3.3)$ & $<0.001$ \\
\hline Snellen acuity & $0.20(0.14)$ & $<0.001$ \\
\hline \multicolumn{3}{|c|}{ VA after 3 months $(n=51)$} \\
\hline LogMar units & $0.81(0.34)$ & $<0.001$ \\
\hline Snellen lines & $15.0(3.4)$ & $<0.001$ \\
\hline Snellen acuity & $0.20(0.14)$ & $<0.001$ \\
\hline \multicolumn{3}{|c|}{ VA after 4 months $(n=37)$} \\
\hline LogMar units & $0.78(0.46)$ & $<0.001$ \\
\hline Snellen lines & $15.4(4.2)$ & 0.001 \\
\hline Snellen acuity & $0.25(0.18)$ & $<0.001$ \\
\hline \multicolumn{3}{|c|}{ VA after 5 months $(n=29)$} \\
\hline LogMar units & $0.86(0.31)$ & 0.034 \\
\hline Snellen lines & $14.5(3.0)$ & 0.046 \\
\hline Snellen acuity & $0.18(0.13)$ & 0.021 \\
\hline \multicolumn{3}{|c|}{ VA after 6 months $(n=25)$} \\
\hline LogMar units & $0.86(0.33)$ & 0.033 \\
\hline Snellen lines & $14.2(3.36)$ & 0.099 (NS) \\
\hline Snellen acuity & $0.18(0.13)$ & 0.068 (NS) \\
\hline \multicolumn{3}{|c|}{ VA affer 7 months $(n=18)$} \\
\hline LogMar units & $0.89(0.59)$ & 0.042 \\
\hline Snellen lines & 14.6 (4.3) & 0.020 (NS) \\
\hline Snellen acuity & $0.19(0.12)$ & 0.006 \\
\hline \multicolumn{3}{|c|}{ VA after 8 months $(n=20)$} \\
\hline LogMar units & $0.83(0.31)$ & 0.17 (NS) \\
\hline Snellen lines & $14.7(3.1)$ & 0.17 (NS) \\
\hline Snellen acuity & $0.19(0.13)$ & 0.18 (NS) \\
\hline \multicolumn{3}{|c|}{ VA after 9 months $(n=16)$} \\
\hline LogMar units & $0.92(0.43)$ & 0.22 (NS) \\
\hline Snellen lines & 13.9 (4.3) & 0.19 (NS) \\
\hline Snellen acuity & $0.19(0.18)$ & 0.068 (NS) \\
\hline \multicolumn{3}{|c|}{ VA after 10 months $(n=9)$} \\
\hline LogMar units & $0.92(0.43)$ & 0.22 (NS) \\
\hline Snellen lines & $13.4(3.8)$ & 0.93 (NS) \\
\hline Snellen acuity & $0.15(0.11)$ & 0.87 (NS) \\
\hline \multicolumn{3}{|c|}{ VA after 11 months $(n=9)$} \\
\hline LogMar units & $1.03(0.41)$ & 0.27 (NS) \\
\hline Snellen lines & $12.8(4.1)$ & 0.27 (NS) \\
\hline Snellen acuity & $0.14(0.14)$ & 0.27 (NS) \\
\hline VA after 12 mon & & \\
\hline LogMar units & $0.90(0.30)$ & 0.55 (NS) \\
\hline Snellen lines & $14.0(3.0)$ & 0.55 (NS) \\
\hline Snellen acuity & $0.16(0.12)$ & 0.40 (NS) \\
\hline VA after 13 mon & & \\
\hline LogMar units & $0.90(0.38)$ & 1.00 (NS) \\
\hline Snellen lines & $14.0(3.9)$ & 0.79 (NS) \\
\hline Snellen acuity & $0.16(0.11)$ & 0.59 (NS) \\
\hline VA after 14 mon & & \\
\hline LogMar units & $1.21(0.14)$ & 0.46 (NS) \\
\hline Snellen lines & $11.0(1.4)$ & 0.46 (NS) \\
\hline Snellen acuity & $0.07(0.02)$ & 0.47 (NS) \\
\hline VA after 15 mon & & \\
\hline LogMar units & $1.01(0.29)$ & 0.24 (NS) \\
\hline Snellen lines & $13.0(2.9)$ & 0.33 (NS) \\
\hline Snellen acuity & $0.12(0.08)$ & 0.18 (NS) \\
\hline
\end{tabular}

*Statistical significance of difference between baseline and follow up data.

NS, statistically not significant. Results presented as mean (standard deviation).

lines-were highly significant $(p<0.001)$ (table 1$)$. The same is true when we were compared the study group and control group matched for preoperative VA with each other (table 2). Taking the whole study population, the number of patients showing an increase in best VA by two or more Snellen lines

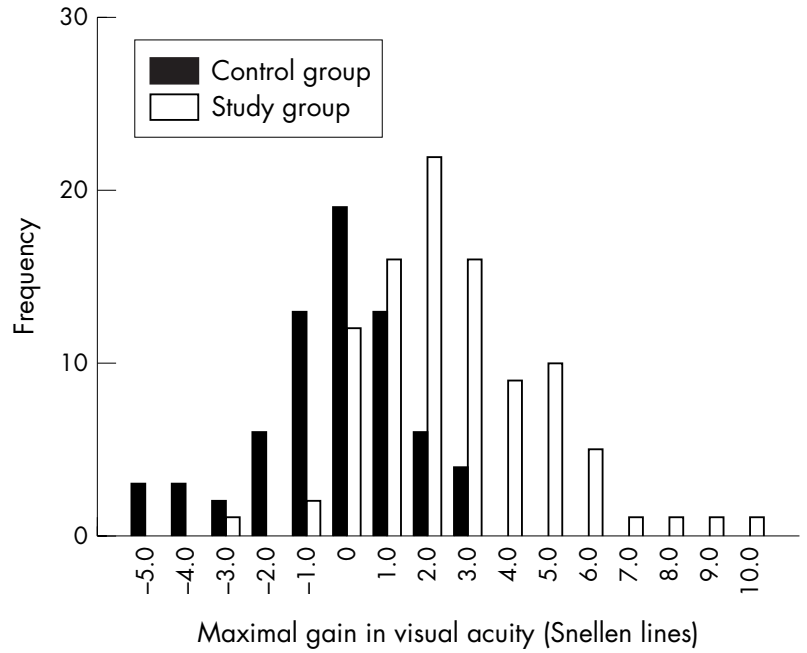

Figure 1 Histogram showing the distribution of change in best visual acuity during follow up.

during follow up was significantly higher in the study group than in the control group $\left(\mathrm{p}<0.001 ; \chi^{2}\right.$ test) (fig 1$)$. The number of patients with a decrease of two or more Snellen lines was significantly $(\mathrm{p}<0.001)$ higher in the control group. Taking into account the study group and control group matched for preoperative VA with each other, similar results were obtained: the number of patients with an increase in best VA of two or more Snellen lines was significantly $(\mathrm{p}<0.001)$ higher, and the number of patients with a decrease of two or more Snellen lines was significantly $(p=0.002)$ lower in the study group than in the control group.

Looking at the measurements obtained at the individual follow up dates, gain in VA was significantly $(p<0.05)$ more marked in the study group than in the control group for the measurements taken at 1-7 months after baseline (table 4) (figs 1 and 2). For the measurements obtained 8 months or later after start of the study, the differences between the study group and control group were statistically not significant. One of the reasons might have been that for reexaminations taken $\geqslant 8$ months after baseline, the decreasing number of patients included became too small for a statistical analysis. The study group and control group varied significantly $(p<0.05)$ in the difference of VA values at study end minus VA values at baseline: in the control group, final VA was significantly worse than at baseline, while in the study group final VA did not vary significantly between end of follow up and baseline (tables 1 and 2).

In the study group, IOP increased significantly $(\mathrm{p}<0.001$; Wilcoxon test) from 15.2 (SD 3.6 ) $\mathrm{mm} \mathrm{Hg}$ (median $16 \mathrm{~mm} \mathrm{Hg}$ ) at baseline of the study to a mean maximum of 21.3 (SD 6.9) $\mathrm{mm} \mathrm{Hg}$ (median $20 \mathrm{~mm} \mathrm{Hg}$ ), and again decreased significantly $\mathrm{p}<0.001)$ towards the end of follow up to a mean of 17.0 (SD 6.3) $\mathrm{mm} \mathrm{Hg}$ (median $16 \mathrm{~mm} \mathrm{Hg}$ ). Forty $(41 \%)$ eyes developed a maximal IOP higher than $21 \mathrm{~mm} \mathrm{Hg}$. The IOP measurement at the end of follow up was however slightly significantly $(p=0.03)$ higher than the baseline value. In all but one eye in which it was increased, IOP could be regulated by topical ant glaucomatous medication. One $(1 \%)$ eye had to undergo conventional filtering surgery because IOP had risen to values higher than $40 \mathrm{~mm} \mathrm{Hg}$, untreatable by eye drops. In the control group, IOP at baseline and the highest IOP during follow up $(p=0.07)$, as well as IOP at baseline and at the end of follow up $(p=0.61)$ did not differ significantly. The rise in IOP 


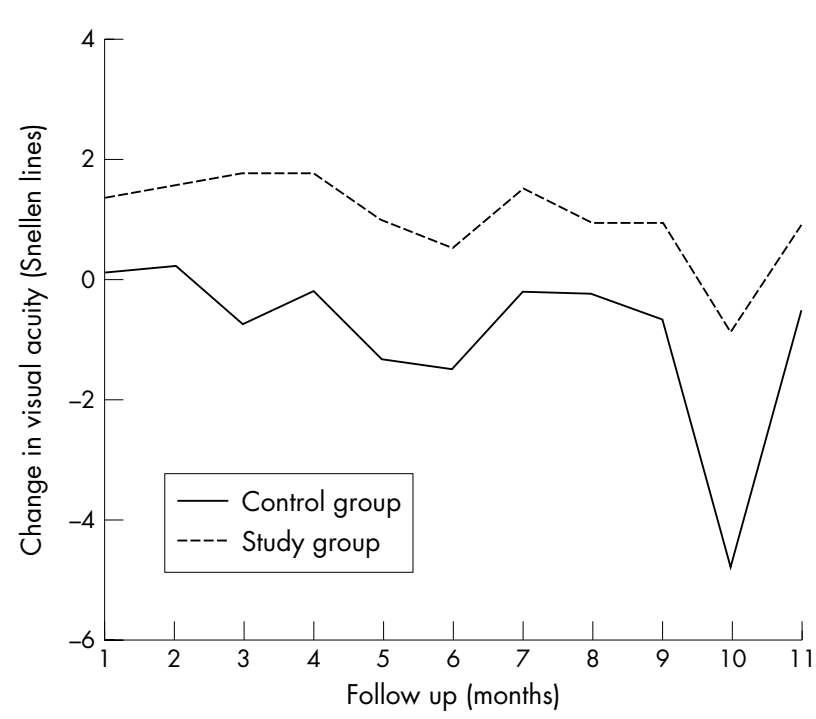

Figure 2 Diagram showing change in visual acuity (expressed in Snellen lines) in the study group and control group during follow up.

during follow up was significantly $(p=0.001)$ higher in the study group than in the control group.

\section{DISCUSSION}

Intravitreal triamcinolone acetonide has increasingly been used in previous studies as treatment for intraocular proliferative, oedematous, and neovascular diseases. ${ }^{7-29}$ The results of the present comparative study suggest that intravitreal triamcinolone acetonide may be useful in increasing VA in patients with diffuse diabetic macular oedema. The patients in the study group compared with the control group showed a significant increase in VA during follow up, expressed in Snellen lines as well as in logMAR units (table 1-4) (figs 1-3). The increase in VA in the study group was most marked for the first 3-6 months after the injection. At the end of the follow up, VA measurements showed a tendency to decrease. Visual acuity measurements obtained at the end of follow up, however, were still significantly higher $(p=0.02)$ than those obtained at baseline. In the control group, VA decreased significantly $(p<0.05)$ during follow up compared with baseline values. At the end of follow up, VA measurements were significantly $(\mathrm{p}<0.001)$ lower than at start of the study.

Based on the results of the present prospective comparative investigation, and in agreement with other studies, ${ }^{1-4}{ }^{30}$ one may infer that patients with persisting diffuse diabetic macular oedema may undergo intravitreal injection of triamcinolone acetonide in a controlled manner. There are, however, limitations of the present study. The most important limitation is the design as a non-randomised, comparative clinical investigation. Another limitation of the study might be that, although intravitreal triamcinolone will have increased the degree of cataract, cataract surgery was not performed in combination with, or after, the intravitreal injection of triamcinolone acetonide during follow up. The vision reducing effect of progressive cataract, however, might have hidden parts of a vision improving effect of triamcinolone so that this limitation of the study might serve to support the conclusion. Another limitation may be that the observer was not masked and usually knew whether the patient had received an intravitreal injection of triamcinolone acetonide.

An additional limitation of this study might be the relatively high dosage of triamcinolone acetonide injected
Table 4 Follow up data of the study group patients and whole control group

\begin{tabular}{|c|c|c|c|}
\hline $\begin{array}{l}\text { Change in } \\
\text { visual acuity }\end{array}$ & Study group & Control group & p Value* \\
\hline \multicolumn{4}{|c|}{1 week after baseline } \\
\hline Number & 57 & 5 & \\
\hline LogMar units & $-0.09(0.18)$ & $-0.02(0.04)$ & 0.36 (NS) \\
\hline Snellen lines & $0.9(1.9)$ & $0.2(0.4)$ & 0.39 (NS) \\
\hline Snellen acuity & $0.04(0.10)$ & $0.01(0.02)$ & 0.51 (NS) \\
\hline \multicolumn{4}{|c|}{1 month after baseline } \\
\hline Number & 64 & 19 & \\
\hline LogMar units & $-0.15(0.28)$ & $-0.01(0.13)$ & 0.006 \\
\hline Snellen lines & $1.3(2.6)$ & $0.1(1.3)$ & 0.01 \\
\hline Snellen acuity & $0.07(0.12)$ & $-0.01(0.07)$ & 0.01 \\
\hline \multicolumn{4}{|c|}{2 months after baseline } \\
\hline Number & 52 & 24 & \\
\hline LogMar units & $-0.16(0.26)$ & $0.00(0.25)$ & 0.009 \\
\hline Snellen lines & $1.5(2.6)$ & $0.2(1.7)$ & 0.027 \\
\hline Snellen acuity & $0.07(0.12)$ & $0.02(0.08)$ & 0.10 (NS) \\
\hline \multicolumn{4}{|c|}{3 months after baseline } \\
\hline Number & 51 & 25 & \\
\hline LogMar units & $-0.19(0.26)$ & $0.09(0.25)$ & $<0.001$ \\
\hline Snellen lines & $1.8(2.2)$ & $-0.7(1.9)$ & $<0.001$ \\
\hline Snellen acuity & $0.07(0.09)$ & $-0.04(0.10)$ & $<0.001$ \\
\hline \multicolumn{4}{|c|}{4 months after baseline } \\
\hline Number & 37 & 19 & \\
\hline LogMar units & $-0.16(0.35)$ & $0.02(0.17)$ & 0.004 \\
\hline Snellen lines & $1.8(3.1)$ & $-0.2(1.7)$ & 0.006 \\
\hline Snellen acuity & $0.10(0.15)$ & $-0.01(0.07)$ & 0.005 \\
\hline \multicolumn{4}{|c|}{5 months after baseline } \\
\hline Number & 29 & 14 & \\
\hline LogMar units & $-0.10(0.25)$ & $0.13(0.20)$ & 0.001 \\
\hline Snellen lines & $1.0(2.5)$ & $-1.4(2.0)$ & 0.002 \\
\hline Snellen acuity & $0.04(0.10)$ & $-0.08(0.12)$ & 0.001 \\
\hline \multicolumn{4}{|c|}{6 months after baseline } \\
\hline Number & 25 & 10 & \\
\hline LogMar units & $-0.06(0.21)$ & $0.15(0.15)$ & 0.003 \\
\hline Snellen lines & $0.5(2.1)$ & $-1.5(1.6)$ & 0.004 \\
\hline Snellen acuity & $0.03(0.08)$ & $-0.11(0.13)$ & 0.001 \\
\hline \multicolumn{4}{|c|}{7 months after baseline } \\
\hline Number & 18 & 16 & \\
\hline LogMar units & $-0.13(0.28)$ & $0.02(0.17)$ & 0.037 \\
\hline Snellen lines & $1.5(2.4)$ & $0.2(1.6)$ & 0.029 \\
\hline Snellen acuity & $0.07(0.09)$ & $-0.02(0.07)$ & 0.011 \\
\hline \multicolumn{4}{|c|}{8 months after baseline } \\
\hline Number & 20 & 13 & \\
\hline LogMar units & $-0.09(0.33)$ & $0.03(0.14)$ & 0.15 (NS) \\
\hline Snellen lines & $1.0(3.3)$ & $-0.2(1.5)$ & 0.18 (NS) \\
\hline Snellen acuity & $0.04(0.16)$ & $-0.02(0.06)$ & 0.17 (NS) \\
\hline
\end{tabular}

*Statistical significance of difference between study group and control group.

NS, statistically not significant. Results presented as mean (standard deviation).

into the eye. In all preceding studies, injecting intravitreal triamcinolone acetonide as treatment for diffuse diabetic macular oedema or cystoid macular oedema due to various reasons, a dosage of 2-8 $\mathrm{mg}$ was used. The reason we continued to inject about 20-25 mg triamcinolone acetonide was that right from the beginning of our ongoing triamcinolone investigations now involving more than 700 injections for various diseases, we have always used the same dosage of about 20-25 mg of triamcinolone acetonide, and we have not seen yet side effects attributed to high dosage. Future dosage finding studies are necessary to evaluate the optimum dosage in view of tolerability, side effects, and duration of action.

The main side effect of intravitreal triamcinolone acetonide observed in the present study was an increase in IOP. Forty (41\%) eyes developed maximal IOP measurements higher than $21 \mathrm{~mm} \mathrm{Hg}$. As already described in previous studies, ${ }^{31-33}$ the secondary ocular hypertension could usually be treated by topical antiglaucomatous medication without the development of glaucomatous optic nerve damage. One $(1 \%)$ eye underwent penetrating trabeculectomy. It has remained unclear so far, whether and how intensively triamcinolone 

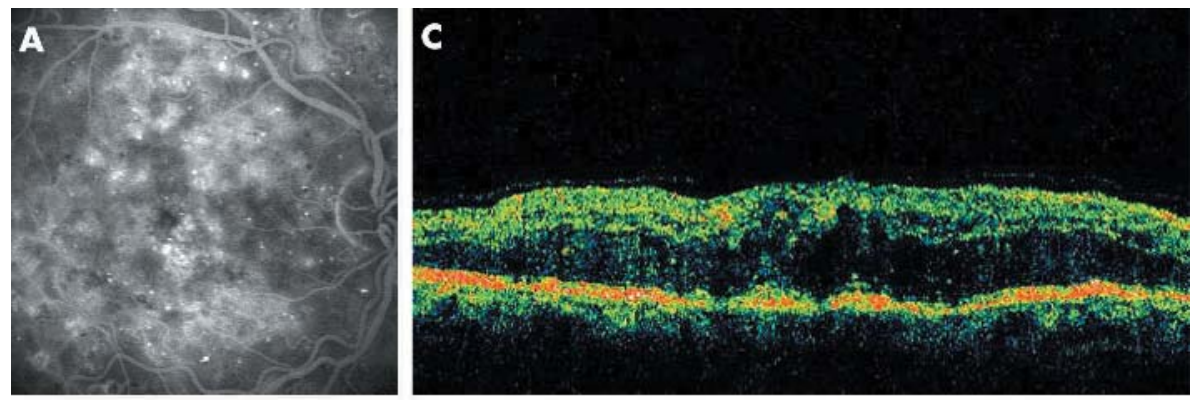

Figure 3 Fluorescein angiography and optical coherence tomography before, and 11 weeks after, intravitreal injection of triamcinolone acetonide. Note: decrease in fluorescein leakage and decrease in retinal thickening parallel to an increase in visual acuity from 0.20 to 0.40 . ( $A$ and $B$ ) fluorescein angiograms; (C and D) optical coherent tomograms.
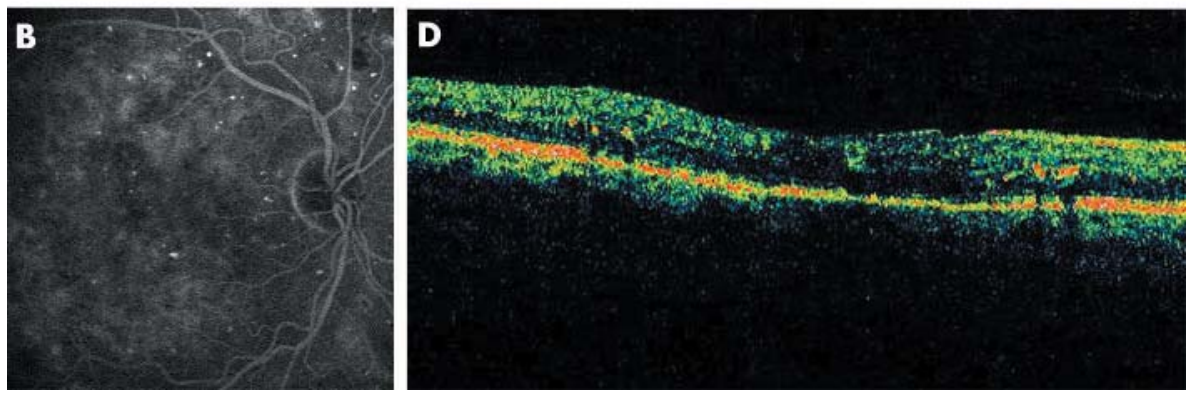

acetonide crystals injected into the vitreous body may influence the vitreoretinal interface. One may suspect that because of their weight, the crystals may lead to a posterior vitreous detachment if the vitreous was not already detached before the injection. A posterior vitreous detachment may increase the risk of rhegmatogenous retinal detachment. So far however, there have been no reports in the literature of a retinal rhegmatogenous detachment as a complication in patients who received an intravitreal injection of triamcinolone acetonide. The advantage of posterior vitreous detachment in patients with diabetic retinopathy may be a reduction of macular oedema as suggested by studies on pars plana vitrectomy in patients with diffuse diabetic macular oedema, and a decreased risk of retinovitreal proliferations. ${ }^{34}$ Future studies may address these topics.

In conclusion, the data in this study suggest that the intravitreal injection of about $20-25 \mathrm{mg}$ of triamcinolone acetonide may improve visual outcome of some patients with diffuse diabetic macular oedema during the first 5-7 months after injection. Future studies evaluating the optimal dosage of triamcinolone acetonide to be injected, the necessity and possibility of intravitreal re-injections, ${ }^{22}{ }^{35} 36$ and comparison of intravitreal injection versus the use of intravitreal slow release devices ${ }^{37}$ are warranted.

\section{Authors' affiliations}

J B Jonas, I Akkoyun, I Kreissig, R F Degenring, Department of Ophthalmology, Faculty of Clinical Medicine Mannheim of the University Heidelberg, Germany

Proprietary interest: none

\section{REFERENCES}

1 Jonas JB, Hayler JK, Söfker A, et al. Intravitreal injection of crystalline cortisone as adjunctive treatment of proliferative diabetic retinopathy. Am J Ophthalmol 2001;131:468-71.

2 Jonas JB, Söfker A. Intraocular injection of crystalline cortisone as adjunctive treatment of diabetic macular edema. Am J Ophthalmo 2001:132:425-7.

3 Martidis A, Duker JS, Greenberg PB, et al. Intravitreal triamcinolone for refractory diabetic macular edema. Ophthalmology 2002;109:920-7.

4 Jonas JB, Kreissig I, Söfker A, et al. Intravitreal injection of triamcinolone acetonide for diabetic macular edema. Arch Ophthalmol 2003;121:57-61.

5 Early Treatment Diabetic Retinopathy Study Research Group. Retinopathy study design and baseline patient characteristics: ETDRS report number 7. Ophthalmology 1991;98:741-56.
6 Classification of diabetic retinopathy from fluorescein angiograms. ETDRS report number 11. Early Treatment Diabetic Retinopathy Study Research Group. Ophthalmology 1991;98:807-22.

7 Greenberg PB, Martidis A, Rogers AH, et al. Intravitreal triamcinolone acetonide for macular oedema due to central retinal vein occlusion. Br J Ophthalmol 2002;86:247-8.

8 Jonas JB, Kreissig I, Degenring RF. Intravitreal triamcinolone acetonide as treatment of macular edema in central retinal vein occlusion. Graef Arch Clin Exp Ophthalmol 2002;240:782-3.

9 Jonas JB, Hayler JK, Söfker A, et al. Regression of neovascular iris vessels by intravitreal injection of crystalline cortisone. J Glaucoma 2001;10:284-7.

10 Jonas JB, Söfker A. Intravitreal triamcinolone acetonide for cataract surgery with iris neovascularisation. J Cataract Refr Surg 2002;28:2040-1.

11 Jonas JB, Hayler JK, Panda-Jonas S. Intravitreal injection of crystalline cortisone as treatment of pre-phthisical ocular hypotony. Graef Arch Clin Exp Ophthalmol $2001 ; 239: 464-5$.

12 Antcliff RJ, Spalton DJ, Stanford MR, et al. Intravitreal triamcinolone for uveitic cystoid macular edema: an optical coherence tomography study. Ophthalmology 2001;108:765-72.

13 Martidis A, Duker JS, Puliafito CA. Intravitreal triamcinolone for refractory cystoid macular edema secondary to birdshot retinochoroidopathy. Arch Ophthalmol 2001;119:1380-3.

14 Young S, Larkin G, Branley M, et al. Safety and efficacy of intravitreal triamcinolone for cystoid macular oedema in uveitis. Clin Experiment Ophthalmol 2001;29:2-6.

15 Degenring $\mathrm{RF}$, Jonas JB. Intravitreal injection of triamcinolone acetonide as treatment of chronic uveitis. Br J Ophthalmol 2003;87:361.

16 Jonas JB. Intravitreal triamcinolone acetonide for treatment of sympathetic ophthalmia. Am J Ophthalmol 2003;136:384-6.

17 Benhamou N, Massin P, Haouchine B, et al. Intravitreal triamcinolone for refractory pseudophakic macular edema. Am J Ophthalmol 2003; 135:246-9.

18 Conway MD, Canakis C, Livir-Rallatos C, et al. Intravitreal triamcinolone acetonide for refractory chronic pseudophakic cystoid macular edema. $J$ Cataract Refract Surg 2003;29:27-33

19 Jonas JB, Kreissig I, Degenring RF. Intravitreal triamcinolone acetonide for pseudophakic cystoid macular edema. Am J Ophthalmol 2003;136:384-6.

20 Penfold PL, Gyory JF, Hunyor AB, et al. Exudative macular degeneration and intravitreal triamcinolone. A pilot study. Aust N Z J Ophthalmol 1995;23:293-8.

21 Danis RP, Ciulla TA, Pratt LM, et al. Intravitreal triamcinolone acetonide in exudative age-related macular degeneration. Retina 2000;20:244-50.

22 Jonas JB, Kreissig I, Degenring RF. Repeated intravitreal injections of triamcinolone acetonide as treatment of progressive exudative age-related macular degeneration. Graef Arch Clin Exp Ophthalmol 2002;240:873-4.

23 Ranson NT, Danis RP, Ciulla TA, et al. Intravitreal triamcinolone in subfoveal recurrence of choroidal neovascularisation after laser treatment in macular degeneration. Br J Ophthalmol 2002;86:527-9.

24 Jonas JB, Kreissig I, Hugger $P$, et al. Intravitreal triamcinolone acetonide for exudative age-related macular degeneration. $\mathrm{Br} J$ Ophthalmol 2003;87:462-8.

25 Gillies MC, Simpson JM, Luo W, et al. A randomized clinical trial of a single dose of intravitreal triamcinolone acetonide for neovascular age-related macular degeneration: one-year results. Arch Ophthalmol 2003;121:667-73. 
26 Jonas JB, Söfker A, Degenring RF. Intravitreal triamcinolone acetonide as additional tool in pars plana vitrectomy for proliferate diabetic retinopathy. Eur J Ophthalmol 2003; 13:468-73.

27 Peyman GA, Cheema R, Conway MD, et al. Triamcinolone acetonide as an aid to visualization of the vitreous and the posterior hyaloid during pars planc vitrectomy. Retina 2000;20:554-5.

28 Alldredge CD, Garretson BR. Intravitreal triamcinolone for the treatment of idiopathic juxtafoveal telangiectasis. Retina 2003;23:113-16.

29 Jonas JB, Kreissig I, Degenring RF. Repeated intravitreal triamcinolone injections as treatment of ischemic ophthalmopathy. Eur J Ophthalmol 2003:13:575-6.

30 Massin P, Audren F, Haouchine B, et al. Intravitreal triamcinolone acetonide for diabetic diffuse macular edema: preliminary results of a prospective controlled trial. Ophthalmology 2004;111:218-24; discussion $224-5$

31 Wingate RJ, Beaumont PE. Intravitreal triamcinolone and elevated intraocular pressure. Aust N Z J Ophthalmol 1999;27:431-2.
32 Jonas JB, Kreissig I, Degenring R. Intraocular pressure after intravitreal injection of triamcinolone acetonide. $\mathrm{Br} J$ Ophthalmol 2003;87:24-7

33 Jonas JB, Kreissig I, Degenring RF. Secondary chronic open-angle glaucoma after intravitreal triamcinolone acetonide. Arch Ophthalmol 2003:121:729-30.

34 Lewis H, Abrams GW, Blumenkranz MS, et al. Vitrectomy for diabetic macular traction and edema associated with posterior hyaloidal traction. Ophthalmology 1992:99:753-9.

35 Jonas JB, Akkoyun I, Budde WM, et al. Intravitreal re-injection of triamcinolone for exudative age-related macular degeneration. Arch Ophthalmol 2004;122:218-22.

36 Jonas JB, Kreissig I, Degenring RF, et al. Repeated intravitreal injection of triamcinolone acetonide for diffuse diabetic macular oedema. Br J Ophthalmol 2005;89:122.

37 Jaffe GJ, Ben-nun J, Guo H, et al. Fluocinolone acetonide sustained drug delivery device to treat severe uveitis. Ophthalmology 2000;107:2024-33.

\section{Video reports}

To view the video reports in full visit our website www.bjophthalmol.com and click on the link to the video reports.

- Giant pleomorphic adenoma of the lacrimal gland: pre- and post-operative function. A Jain, VI Nehru, U N Saikia, C E E Reddy

- Limbal-sparing lamellar keratoplasty. S L Watson, S Rauz, J Dart

- Bilateral Abducens Neuromyotonia. L H Ospina, N Aui-aree, D P Anderson

- Light to dark physiological variation in irido-trabecular angle width. GM Gazzard, P J Foster, D S Friedman, P T Khaw, S K L Seah

Video Suite: Triamcinolone-assisted vitrectomy

- Triamcinolone-assisted removal of the posterior hyaloid to repair retinal detachment due to macular hole in high myopia. A Ueno, H Enaida, Y Hata, T Nakamura, T Hisatomi, K Fujisawa, T Kubota, T Sakamoto, T Ishibashi

- Triamcinolone acetonide-assisted Epiretinal Membrane Peeling. S D M Chen, C K Patel

- A suture technique to manage a case of severe early flap displacement after laser in situ keratomileusis. L Spadea, P Pantaleoni, G Bianco

- Reconstruction of the Ocular Surface in LOGIC Syndrome. E Moore, V Kumar, J R Ainsworth, S Shah

- Laser Photocoagulation for Posterior Segment Intraocular Parasites. T Prabriputaloong, S Asawaphureekorn

- Feeder Vessel Treatment with High Speed ICG Angiography. D Stanescu-Segall, $G$ Coscas, $F$ Coscas, G Soubrane

- Endoscopy to aid anterior segment surgery. J E Moore, A Sharm

- Penetrating ocular injury due to a fish hook: Surgical removal. SD M Chen, D Chiu, C K Patel

- Retinal Ganglion Cell Axon Response to Guidance Molecules. S F Oster and DW Sretavan

- Marin-Amat Syndrome. A Jogiya, C Sandy

- Excision of subcutaneous Dirofilariasis of the eyelid. D Mallick, TP Ittyerah

- Thixotropy: a novel explanation for the cause of lagophthalmos after peripheral facial nerve palsy. M Aramideh, J H T M Koelman, P P Devriese, F VanderWerf, JD Speelman

- Surgical revision of leaking filtering blebs with an autologous conjunctival graft. KTaherian, A Azuara-Blanco

- Dipetalonema Reconditum in the human eye. THuynh, J Thean, R Maini 